\title{
Interactions of antilipoidal antibodies with yolk sac antigens
}

\author{
A. LASSUS AND E. A. JOHANSON \\ Department of Dermatology and Venereology, University Central Hospital, Helsinki \\ C-E. SONCK \\ Department of Dermatology, University of Turku, Finland \\ K. AHO \\ State Serum Institute, Helsinki, Finland
}

The complement-fixation tests for antibodies to psittacosis-lymphogranuloma venereum agents exhibit a high degree of cross-reactivity within the group; but nonspecific reactions are rare. Sera of patients with syphilis seem to provide an exception, since they have frequently been found to react nonspecifically with both ornithosis and lymphogranuloma venereum (LGV) antigens. The nonspecific nature of these reactions is easily established since the sera also react with the control antigen. Much interest was formerly focused on this problem, but the results of epidemiological studies performed at that time were difficult to interpret because of the frequent concurrence of $\mathrm{LGV}$ in cases of syphilis. Little attention has recently been paid to the problem, despite the advent of specific treponemal tests and useful methods of serum fractionation.

Approaching the problem from the other direction, patients infected with ornithosis often have acute biological false positive (BFP) seroreactions for syphilis (Löffler, 1959), and the frequent occurrence of syphilis in patients with LGV makes it difficult to establish the cause of positive seroreactions for syphilis in such patients. However, it is evident that acute BFP reactions also occur in connection with LGV (Heyman and Webb, 1946).

In the present study, syphilitic and BFP-sera have been tested for complement-fixing antibodies against yolk sac antigens, and dermal hypersensitivity against this type of antigen (Frei test) has been looked for in patients with syphilis and BFP reactions.

\section{Material and methods}

SERA WITH ANTILIPOIDAL ANTIBODIES

Sixteen sera were from darkfield positive patients with primary or secondary syphilis, and 36 from patients with latent or late symptomatic syphilis. The latter were positive in both the Treponema pallidum immobilization (TPI) and fluorescent treponemal antibody-absorption

Received for publication September 16, 1970

Address for reprints: Prof. A. Lassus, Snellmanink, 14, Helsinki 17, Finland
(FTA-ABS) tests; and were selected so that they had Venereal Disease Research Laboratory (VDRL) titres corresponding to those seen in the patients with primary or secondary syphilis.

Three high-titred BFP sera have been described elsewhere (Aho, 1969). Twelve other BFP sera were selected from specimens sent in for routine TPI and FTA-ABS testing.

\section{PATIENTS}

In only a few cases were both serum tests and skin testing performed in the same patient: 31 patients had syphilts (seven primary, nine secondary, eleven treated latento and four late symptomatic). They all had a positive result to the FTA-ABS test and a VDRL titre $\geqslant 4$.

Sera from 43 patients exhibited the chronic BFP reaction; six of these had definite and eleven probable systemic lupus erythematosus (SLE) (Mustakallio, Lassus, and Putkonen, 1966).

Thirty patients had long-standing treated LGV. They had all received sulphonamides about 30 years before the present study. The Frei test, which had been positive in all cases before this treatment, was still positive in 21 cases.

TESTS FOR SYPHILITIC ANTIBODIES

These were performed according to standard techniques as described elsewhere (Aho, 1967).

TESTS FOR ORNITHOSIS ANTIBODIES

Tests for complement-fixing antibodies were effected by the micro method (Fulton and Dumbell, 1949), using two units of complement. Two BFP sera were anticomplementary with this technique. The anticomplementary phenomena could be avoided by using the tube technique. An ornithosis antigen from Behringwerke and a lygranum antigen from Lederle were used as antigens. A control antigen was available only from Lederle.

\section{FRACTIONATION PROCEDURES}

Density gradient ultracentrifugations were performed in a 10 to 40 per cent. sucrose gradient. The $S W 50 \mathrm{~L}$ rotor and Spinco model L 50 ultracentrifuges were employed in a $16-\mathrm{hr}$ run at 40,000 r.p.m. Nine successive $0.5 \mathrm{ml}$. fractions were collected by puncturing the tubes through the bottom in a fractionating apparatus (Beckman). 


\section{FREI TEST}

The skin tests were performed with a lygranum antigen and a control antigen from Lederle.

\section{Results}

The ornithosis (Behringwerke antigen) and VDRL titres in the sera of 52 patients with confirmed syphilis are presented in the Table, which shows that the titres of the two test systems correlated fairly well. No difference in the ornithosis titre could be found when correlating it with the stage of syphilis. When Lederle lygranum antigen was used, the titre was usually slightly weaker than when the Behringwerke antigen was used. Eighteen of the sera with a raised titre to Lederle antigen could be tested with Lederle control antigen. In four of these, the result was the same as with the lygranum antigen, while in fourteen cases the titre was slightly weaker.

T A B L E Correlation between ornithosis titres and VDRL titres in sera of patients with syphilis

\begin{tabular}{|c|c|c|c|c|c|c|c|c|c|}
\hline \multirow{2}{*}{$\begin{array}{l}\text { Ornithosis } \\
\text { titre }\end{array}$} & \multicolumn{8}{|c|}{ No. of cases with VDRL titre: } & \multirow[b]{2}{*}{ Total cases } \\
\hline & 2 & 4 & 8 & 16 & 32 & 64 & 128 & 256 & \\
\hline $\begin{array}{r}<8 \\
8 \\
16 \\
32 \\
64 \\
128\end{array}$ & 3 & $\begin{array}{l}3 \\
1 \\
1\end{array}$ & $\begin{array}{l}1 \\
4 \\
2\end{array}$ & $\begin{array}{l}3 \\
3 \\
1\end{array}$ & $\begin{array}{l}4 \\
4 \\
2 \\
1\end{array}$ & $\begin{array}{l}4 \\
2 \\
1 \\
1\end{array}$ & $\begin{array}{l}2 \\
3 \\
4\end{array}$ & $\begin{array}{l}1 \\
1\end{array}$ & $\begin{array}{r}7 \\
16 \\
14 \\
7 \\
6 \\
2\end{array}$ \\
\hline Total & 3 & 5 & 7 & 7 & 11 & 8 & 9 & 2 & 52 \\
\hline
\end{tabular}

The sera of 180 pregnant women, who all had a negative VDRL test, were tested with Behringwerke ornithosis antigen. In eight of these the titre was $1: 8$ and in one $1: 32$; all the others were negative.

Three selected sera with strong chronic BFP reactions (Cases 1-3, Table IV: Aho, 1969) also showed high positive titres to both ornithosis antigen and the control antigen. Of the twelve remaining BFP sera, those with a low antilipoidal titre were negative, while the others showed raised titres to the ornithosis antigen and control antigen. The overall incidence of raised ornithosis titres was much higher in the BFP than in the control sera.

The sera of two rabbits with experimental syphilis and high antilipoidal titres also showed high ornithosis titres.

The sera of one patient with ornithosis, of one with late syphilis, and of one with a strong chronic BFP reaction were subjected to fractionation by ultracentrifugation. As shown in the Figure, the ornithosis serum displayed complement-fixing antibodies mainly in the $7 \mathrm{~S}$ fraction, the syphilis serum in both the 7S and 19S fractions, and the BFP serum in the $19 \mathrm{~S}$ fraction only. In the two latter sera, the ornithosis titres paralleled the occurrence of the antilipoidal antibodies.

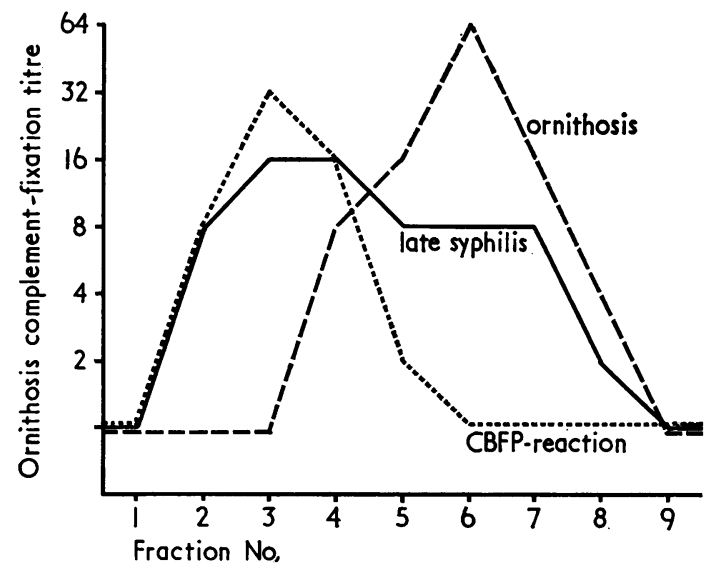

FIGURE Ultracentrifugation of a sera from a case of late syphilis, a patient with CBFP-reaction, and a case of ornithosis

The Frei skin test was performed on 43 patients with a chronic BFP reaction and 31 patients with syphilis. Not one patient reacted to the lygranum antigen or to the corresponding control antigen.

Thirty patients with long-standing treated LGV were tested for syphilis by the FTA-ABS test. In ten of these the results were positive, indicating a past syphilitic infection.

\section{Discussion}

The antigens for ornithosis and lymphogranuloma venereum complement-fixation tests are derived from chick embryo yolk sac. The control antigen is prepared in the same manner from corresponding noninfected tissue. There is a high degree of crossreactivity to the antigens of the different members of the psittacosis-LGV group of agents, but nonspecific complement-fixations seem to be rare. However, sera of syphilitic patients have been found to yield such nonspecific complement-fixation rather frequently, both with ornithosis (Bedson, 1935) and with lygranum antigen (Fløystrup, Reymann, and Reyn, 1950; Grace, Shaffer, and Rake, 1943; Knott, Bernstein, Eagle, Billings, Zobel, and Clark, 1943). The nonspecific nature of the reaction is revealed by similar complement-fixation with the control antigen (Bedson, 1935; Dulaney and Packer, 1947; Grace and others, 1943; Reyn, 1951; Shaffer, Rake, Grace, McKee and Jones, 1941), indicating that the sera react with some antigen of the yolk sac tissue. 
Nonspecific reactions of this type have been found especially in sera of patients with early and florid late syphilis (Grace and others, 1943; Knott and others, 1943), but not in sera of patients with congenital syphilis (Grace and others, 1943). Reyn (1951) found no conformity between the degree of antilipoidal antigen and lygranum titre in syphilitic sera. Knott and others (1943) were able to remove the complement-fixing antibodies to lygranum antigen from some syphilitic sera with syphilis test antigen (Eagle flocculation antigen). This finding was confirmed by Dulaney and Packer (1947), who performed absorption experiments with Kahn antigen. The antisyphilitic treatment of patients with early syphilis, which changed the results of anti-lipoidal tests for syphilis to negative, was also found by Knott and others (1943) to remove the antibodies to lygranum antigen.

The present series of syphilitic patients did not in all probability include any case with LGV, since new cases of this disease have been extremely rare in Finland for over 20 years. A high proportion of the syphilitic sera showed a raised titre of complementfixing antibodies to both the ornithosis and lygranum antigens and to the lygranum control antigen. Raised titres were found in both early and late syphilis, and correlated rather well with the titre of antilipoidal antibodies; this differs from the findings of Reyn (1951). A raised ornithosis titre was rare in the control sera. The sera with high antilipoidal antibody levels from rabbits with experimental syphilis were found to have a high ornithosis titre. The results with the control antigen were often slightly weaker than those with test antigen, but the low frequency of raised ornithosis titres in the control sera suggests that the difference is unlikely to be due to the presence of ornithosis antibodies. More probably it results from antigenic differences between the test and the control antigens, caused by the growth of the organism in the former.

Reyn (1951) found a remarkable number of strong lygranum reactions in sera of patients with respiratory diseases and false positive seroreactions for syphilis, but she did not mention whether these sera reacted with the control antigen also. It seems probable that the positive lygranum reactions in the sera of her patients were caused by some cross-reacting organisms of the psittacosis-LGV group, which are known to cause BFP reactions (Löffler, 1959). We have found no data on positive complement-fixation tests with psittacosis-LGV antigens in the sera of patients with chronic BFP reactions. All three high-titred chronic BFP sera in the present study showed a strong reaction with both the ornithosis antigen and its control antigen. The BFP sera with lower anti- lipoidal titres also showed a higher incidence of raised ornithosis titres than the control sera.

Fractionation by density gradient ultracentrifugation showed that the complement-fixing serological activity occurred almost entirely in the $7 \mathrm{~S}$ fraction in an ornithosis serum; in both the $7 \mathrm{~S}$ and $19 \mathrm{~S}$ fractions in a syphilitic serum; and in the $19 \mathrm{~S}$ fraction only in a chronic BFP serum. In the two latter the ornithosis titre correlated very well with the titres of the antilipoidal antibodies. This is in agreement with the absorption experiment (Dulaney and Packer, 1947; Knott and others, 1943), which suggests that the same antibodies are responsible for Wassermann reactivity and complement-fixation with chick embryo yolk sac antigen.

Positive lygranum skin reactions have also been found in patients with diseases caused by members of the psittacosis-LGV group other than the LGV agent (Reymann, 1951). Some patients with syphilis have been found to have a positive Frei-test in earlier studies (Wetherbee, Hilfer, Maspero, and Kuhns, 1951). Positive Frei-tests are very rare in persons who have never had a venereal infection (Reymann, 1951). Positive Frei-tests in syphilitic patients in whom there is no information regarding earlier LGV infection have been taken as evidence of a latent: LGV rather than of a nonspecific phenomenon. This is supported by the finding in the present study that none of the syphilitic patients tested had a positive Frei-test. In addition, one-third of the patients with long-standing treated LGV had serological evidence of syphilis, indicating the high degree of coincidence of these two diseases in the past.

None of the chronic BFP reactors tested showed a positive reaction to either the lygranum antigen or to its control antigen in the Frei-test. Many of these patients had SLE, a disease known to be associated with dermal hypersensitivity, e.g. to DNA (Ores and Lange, 1964). The relationship of humoural autoantibodies to the tissue manifestations of SLE remains obscure. Tissue destruction is generally held to be caused by cell-mediated immune responses. In this respect it is of some interest that factor analysis has revealed an association between BFP reactivity and carditis in SLE (Mustakallio, Lassus, and Putkonen, 1966).

\section{Summary}

Of 52 syphilitic sera, 45 had an ornithosis titre $\geqslant 8$. Slightly weaker reactions were obtained with the control antigen. The ornithosis titre correlated fairly well with the antilipoidal titre. There were fewer raised titres in control sera. Sera with strong BFP reactions showed high ornithosis titres. Sera with weak BFP reactions also showed a higher in- 
cidence of raised ornithosis titres than control sera. In addition, rabbits with experimental syphilis showed high ornithosis titres. Fractionation by ultracentrifugation showed that an ornithosis serum displayed complement-fixing antibodies mainly in the $7 S$ fraction, a syphilitic serum in both the 7S and $19 S$ fractions, and a BFP serum in the 195 fraction only. It is suggested that the same antibodies were responsible for the Wassermann reactivity and the complement-fixation with chick embryo yolk sac tissues.

Dermal hypersensitivity against lygranum antigen (Frei test) was tested in 31 patients with syphilis, and in 43 patients with a chronic BFP reaction. None of these patients showed a reaction to the lygranum antigen or its control antigen.

Supported by a grant from the Sigrid Jusélius Foundation.

\section{References}

Aно, K. (1967) Brit. F. vener. Dis., 43, 259

(1969) Ibid., 45, 13

Bedson, S. P. (1935) Lancet, 2, 1277

Dulaney, A. D., and PACKER, H. J. (1947) F. Immunol., 55,53

Floystrup, T., Reymann, F., and Reyn, A. (1950) Acta path. microbiol. scand., 27, 94

Fulton, F., and DumbelL, K. R. (1949) f. gen. Microbiol., 3, 97

Grace, A. W., Shaffer, M. F., and Rake, G (1943) Amer. F. Syph., 27, 44

Heyman, A., and WeBb, E. L. (1946) f. vener. Dis. Inform., 27, 122

Knott, L. W., Bernstein, L. H. T., EAgLe, H., BilLINGS, T. E., ZOBEL, R. L., and ClaRK, E. G. (1943) Amer. F. Syph., 27, 657

LöfFLER, H. (1959) Schweiz. Z. allg. Path., 22, 658
Mustakallio, K. K., Lassus, A., and Putkonen, T. (1966) Meth. Inform. Med., 5, 184

Ores, R. O., and LANGe, K. (1964) Amer. F. med. Sci., 248,562

ReymanN, F. (1951) Acta derm.-venereol. (Stock.), 31, 257

REYN, A. (1951) Ibid., 31, 262

ShafFER, M. F., RAKE, G., Grace, A. W., MCKeE, C. M., and Jones, H. P. (1941) Amer. F. Syph., 25, 699

Wetherbee, D. G., Hilfer, R. J., MASPERo, B., and Kunns, D. M. (1951) Amer. F. clin. Path., 21, 521

Interactions des anticorps anti-lipoïdiques avec les antigènes du sac vitellin

\section{SOMMAIRE}

Sur 52 sérums syphilitiques, 45 avaient un titre pour l'ornithose $\geqslant 8$. Des réactions légèrement plus faibles furent obtenues avec l'antigène témoin. Le titre pour l'ornithose fut en bon accord avec le titre anti-lipoïdique. Les titres furent élevés pour les sérums témoins. Les sérums avec de fortes réactions biologiquement faussement positives eurent de hauts titres pour l'ornithose. Les sérums à faible réaction BFP eurent aussi une plus haute incidence de titres élevés pour l'ornithose que les sérums témoins. En outre, les lapins infectés expérimentalement de syphilis montrèrent de haute titres en ornithose. Le fractionnement par ultra-centrifugation montra qu'un sérum positif pour l'ornithose contenait principalement des anticorps de fixation du complément dans la fraction 7S, qu'un sérum syphilitique les contenait aussi bien dans la fraction $7 \mathrm{~S}$ que dans la fraction 19S, et qu'un sérum BFP les contenait seulement dans la fraction 19S. On pense que les mêmes anticorps sont responsables de la réactivité Wassermann et de la fixation du complément avec le tissu du sac vitellin de l'embryon de poulet.

L'intra-dermo réaction avec l'antigène "lygranum" (épreuve de Frei) a été étudiée chez 31 syphilitiques et chez 43 sujets présentant une réaction BFP chronique. Aucun de ces malades ne donna de réponse à l'antigène lygranum ou à l'antigène témoin. 